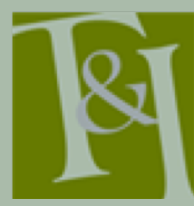

The International Journal for Translation \& Interpreting Research trans-int.org

\section{Corpus Linguistics approaches to trainee translators' framing practice in news translation}

Yun Pan

Shanghai Maritime University, China

ypan@shmtu.edu.cn

DOI : 10.12807/ti.112201.2020.a06

\begin{abstract}
This article presents an empirical linguistic case study of seven Chinese ${ }^{1}$ trainee translators' framing practice, focusing on how they reconstructed key lexical concepts in an English-to-Chinese news translation task. The research aim was to demonstrate how frames conceptualized in Frame Semantics (Fillmore, 1982) rationally serve as analytical and interpretive units of meaning, which contributes to providing a structural description and sufficient interpretation of translational discourse. The findings suggest that frames as context-motivated knowledge structures are crucial units of meaning to interrogate both source texts and translated texts in translation practice. This study has implications in translation training concerning how knowledge of frame application enters into training practice for source text interpretation and target text production.
\end{abstract}

Keywords: news translation; frame and framing; Corpus Linguistics; semantic tagging

\section{Introduction}

Translation as mediated text production for specific communicative purposes plays an increasingly important role in social transaction of knowledge across languages and cultures. Translation is inherently situated and heterogeneous rather than being practiced de-contextually or uni-dimensionally (Tymoczko \& Gentzler, 2002). Knowledge transfer through translational mediation relies on reconstruction of the realities constructed by professionals through institutional discourses in the source language (Tuchman, 1978). The re-construction process is primarily executed and constantly evaluated by the translator through his/her discursive management of units of knowledge representation between the source text and the target text. Frames (Fillmore, 1982; Minsky, 1974), as units of schematic meaning, have seen increasing popularity in the understanding of mass communication (Darwish, 2006) and analysis in media studies. Frames are knowledge structures containing systems of categories and categorical associations. They have been widely taken as psychological devices offering perspectives and manipulating judgments (Rhoads, 1997). Lexical concepts are deeply grounded in frames and serve to modify conceptual structures for translation strategy use. The (re-)construction of meaning, therefore, is expected to be most salient and dynamic at the semantic level. It is within certain knowledge structures (rather than isolated sentences) that linguistic choices in the source text can be effectively examined, interpreted, and translated. This article argues that frames evoked by certain lexis in the source text are legitimate units of meaning to examine and evaluate translated

1 "Chinese" is used here to mean that the participants were born and raised in Mainland China and are native speakers of Mandarin Chinese. 
texts and that it is important to investigate patterns of the target text and reflective language use in a complete translation task cycle.

\section{Frame and framing in translation studies}

Translational behaviour is different from other types of linguistic behaviours (Baker, 1993) in terms of text production, which involves the translator's explicative intention to transfer the 'meaning' he/she has inferred from the source text to the translated text. The guided meaning construction at the textual level depends on the negotiation between the author of the source text, the translator, and the audience of the translated text. Unlike what is in other types of social communication for knowing, the 'negotiation of meaning' (Fauconnier, 1997, p.1-33; Gass, 1997; Pica, 1994; Rommetveit, 1992; Stahl, 2006) in translation is not simultaneous among participants, but inevitably constrained by time and space. As a result, even the commonest communicative trouble which would be easily tackled through on-line interaction can impose great challenges even obstacles on the translation task. Nevertheless, how meaning is negotiated and constructed in translation sticks to the basics of communicative text production: it relies on the combination of units of 'knowledge' as mental representations (see Bednarek, 2005; Cook, 2009; Evans, 2009; Hamawand, 2016; Tannen, 1993; Yule, 1996) of human experience (see Brinton, 2000; Petruck, 1996; Telles-Ribeiro \& Hoyle, 2009). If translation can be taken as a trilateral interaction, the translator-led negotiation of meaning is expected to have a shaping power over the 'structure' of the interaction (see Pica, 1994), namely, the way in which his/her translation is to be produced, organized, and processed. Such a textual structure consists of smaller structures integrated in an economical way but probably at higher conceptual levels.

In this study, I investigated the linguistic dimension of meaning-making in translation by focusing on a research entity called 'knowledge structures', or, 'frames' 2. Minsky (1974) first used the term 'frame' for knowledge representation to refer to "a data-structure for representing a stereotyped situation" (p. 3). 'Frame' in Frame Semantics is defined by Fillmore (1982) as "a system of categories structured in accordance with some motivating context" (p. 381). The cognitive-communicative duality of discursive framing (Pan, 2017) has theoretical implications in the field of translation studies, in which analysis of frame and framing contributes to understanding translational behaviours. At the cognitive level, grammatical and semantic categories in the source text impose their frames on the textual material they structure, which would greatly impact how the translator interprets the discursive features of the text informed and shaped by the frames. The syntactic and lexical patterns which are observable in the source text "evoke" relevant frames in the mind of the translator. He/she then assigns coherence to the translated text by "invoking a particular interpretive frame" (Fillmore, 1982, p.385).

At the interactive level, the "subjective involvement" (Goffman, 1986, p.10) of the translator is highlighted in the translation process in a sense that he/she re-shuffles the cues (Bateson, 1972) retrieved from the source text and re-organizes the frames in a coherent way into the translated text. The translator takes up the role to predict new information, events, and experiences (Tannen, 1993 ) for the target audience of the translated text. The re-shuffling and reorganizing processes feature implicit meaning negotiation (Drake \& Donohue,

\footnotetext{
2 Studies involving analysis of frames as the focus or methodology have drawn from various theoretical approaches, which leads to working definitions of a "frame" that are often rather tentative and highly specific to particular research purposes (Touri \& Koteyko, 2014, p.2). In this study, frames in the target texts are operationalized and examined, with an empirical orientation of data analysis, draws from the linguistic approach developed from Frame Semantics (Fillmore, 1982).
} 
1996) between the source text, the translator and the target audience through the translator's linguistic choices. It is in this process that the translator is expected to play an active rather than a subordinate role by "replaying" (Goffman, 1974, p.504) the scene activated from the source text. The target audience, assisted by the translator, can "empathetically insert themselves into" (Goffman, 1974, p.504) the reproduced scene.

The notion of 'frame' highlights "the semantic supporting function of domains for concepts" (Clausner \& Croft, 1999, p.1). The process of meaning negotiation directed by the translator relies on the combination of different concepts. A 'concept' is commonly perceived as a "unit of knowledge created by a unique combination of characteristics" (Object Management Group, 2015, p.26). Lexical concepts are "recognized as grounded in" frames (Fillmore, 1982, p.382). They are fundamental linguistic devices for meaning construction (Evans, 2009), through which the translator invokes frames for the target audience of the translated text. In the conceptual system, "a concept takes a form of a 'conceptual structure', knowledge representation assembled for purposes of meaning construction" (Hamawand, 2016, p.83). For instance, metaphor is one of the most typical conceptual structures, and has been long a real challenge to translation in practice. Metaphors are effective for meaning conveying since they express "an identity in structure between different domains" (Gärdenfors, 2014, p.39), thus "preserve the cognitive topology" between "the source domain" and "the target domain" (Lakoff, 1993, p.215). Unlike the classical view which sees metaphor as a figurative use of language, Frame Semantics views it as modelled in terms of 'mapping' between two things from different areas of knowledge (Hamawand, 2016, p.85). Metaphor in such sense is "a device employed to explain the nature of complex issues or hard-tounderstand ideas" (Hamawand, 2016, p.85). A metaphorical expression in the source text serves to highlight individual aspect(s) of a particular concept. To what extent the translator is able to reconstruct these aspects determines the accessibility of the concept in the translated text to the target audience.

Conceptual structures represented by lexical structures in translated texts are "built up semantically and pragmatically at the same time" (Fauconnier, 1997, p.70). It goes against the traditional view of meaning representation in total (or literal) translation that meaning is a property of a language itself (see Catford, 1965). Viewed from a usage-based perspective, lexical meaning retrieved from the translator's interpretation of the source text is highly flexible and context-dependent (Langacker, 1987). Words in the source text are taken as "contextual expressions", and meaning is believed to be "assigned" rather than "carried" by associated words in utterances" (Evans, 2009, p. 22). Therefore, the scope of the translator's search for a so-called 'equivalent' should be expanded beyond the word boundary. A particular linguistic form in the source text is seen to be with 'meaning potentials' rather than a definite 'meaning' (Allwood, 2003). The meaning potentials provide access sites (Evans, 2006) to a particular frame, within which lexical concepts are functionally interpreted and transferred. A higher level of meaning construction in the translated text can be realized then.

Analysis of frame and framing in translation studies liberates a theory from the traditional dichotomy of word-for-word or sense-for-sense translation (Melamed, 1997). The approach is expected to connect structures and systems of language use and those in situated contexts of translation (Firth, 1968), thus contributes to developing a descriptive branch of translation studies (Toury, 1980) based on "verification" and "falsification" (Holmes, 1988, p.101). Previous work has been done to evaluate the use of Frame Semantics for lexis translations (e.g. López, María, \& Valenzuela, 1998), word sense translation (e.g. Fung, 2006), communication verbs in speaking events (e.g. Shi, 2008), and the transfer of semantic information across different languages (e.g. Basili, Cao, Croce, Coppola, \& Moschitti, 2009). 
More recent studies focus on how the analysis inspired by Frame Semantics contributes to characterizing linguistic variation in translation. The universality of frames has been explored in translation to reveal the crosslinguistic applicability of semantic constructions. For example, Hedegaard and Simonsen (2011) explore the usefulness of frame-based classifiers for author attribution of translated texts. Wang (2012) specifically focuses on frameinspired translation strategies in legal translation. Čulo (2013) investigates patterns of frame shifts in translations between English and German, highlighting the interplay between construction and frame divergences in translation practice. Hasegawa, Lee-Goldman, and Fillmore (2014) examine English-to-Japanese translations to see whether frames annotated for source texts can function as a useful tool to assess the accuracy of translated texts. Bäckström, Lyngfelt, and Sköldberg (2014) address the possibility of linking semantic frames as construction resources for English-to-Swedish translations.

Frame analysis has been increasingly used in research on news discourse since the early 1990s. Efforts have been made to integrate psychological and sociological dimensions of frames and framing to characterize news discourse following Goffman's (1974) seminal work on human social interaction. Framings of both the news text producer and the audience are viewed as highly relevant to the construction of meaning (Touri \& Koteyko, 2014). Pan and Kosicki (1993) saw framing as "a strategy of constructing and processing news discourse" since it involves applying "cognitive device in information encoding, interpreting, and retrieving" (p. 57). Carragee and Roefs (2004), problematizing the existing conceptual approaches to framing in news text analysis, argued that framing processes need to be examined "within the context of the distribution of political and social power" (p. 214). Some analyses applied predetermined framing categories or well-established coding systems (e.g. Entman, 1991; Semetko \& Valkenburg, 2000; Snow \& Benford, 1988; Tankard, 2001). More empirical approaches focus on the emerging mechanism of framing in news discourse (e.g. Boni, 2002; Coleman \& Dysart, 2005; Esser \& D'Angelo, 2003, some of which owe a great deal to computer-assisted quantitative identification and qualitative analysis of semantic frames (e.g. Touri \& Koteyko, 2014; Trenz, 2004; van de Steeg, Rauer, Rivet, \& Risse 2003).

Frames and framing in news translation, especially how lexically invoked frames can be interpreted from an analytical perspective adopted by the translator, however, has not received enough attention in the field of translation studies. The transfer of particular framing categories from the source text to the translated text, whether the categories are inductively or deductively identified, has become increasingly challenging. One of the reasons is that a mediative dimension is added to the reception of the source text when the translator is involved. The identification of frames, therefore, can only serve as a starting point and a comparative benchmark rather than the ultimate goal in the analysis of news translation discourse. To see how the translator plays an active role mediating the news production and audiences' information processing, one should also take into account the translator's reflective practice. However, there is a lack of close, in-depth observations of the complete operational cycle (which includes the source text, the translate text, and the translator's explicit reflection). The current study aims to narrow the gap by demonstrating how semantic frames rationally serve as identifiable and analytic units of meaning to interpret translational discourse.

\section{Corpus Linguistics approaches to translation studies}

The word corpus originates from the Latin for 'body' (with the plural form corpora). It is defined by Baker, Hardie, and McEnery (2006) as "a collection of texts stored in an electronic database" containing a large number of words of 
"machine-readable text" (p. 48). The counts of linguistic forms are readily identifiable for a computer, thus, can highlight some kind of regularity of language in use. Such patterned language use may otherwise be overlooked due to the researcher's intuition (Laviosa 2011, p.137) ${ }^{3}$. Corpus Linguistics approaches have obvious strengths in investigating language in use by employing bottom-up processing methods, as opposed to some traditional linguistic studies which tend to exclusively focus on language structures. Corpus analyses are inherently compatible with various analytical techniques and can be applied as a complementary approach to many other approaches in language research and other disciplines as well.

Nowadays, trainee translators use increasingly advanced language technologies, of which corpus-based approaches are an essential part (Laviosa 2011, p.144). Corpus Linguistics offers translation scholars and practitioners "a powerful set of tools that have already revolutionized the study of language" in translational discourse (Baker, 1999, p.281-282). Previous research has shown the merits of Corpus Linguistics methods applied in translation studies (e.g. Baker, 2004; Granger, Lerot \& Petch-Tyson, 2003; Kenny, 2009, 2014; Laviosa, 1998, 2002). Corpus Linguistics research investigates relations between "frequency" and "typicality", and "instance" and "norm" (Stubbs, 2001, p.151). The relations are to be explicated upon a descriptive basis (Toury, $1978)^{4}$, with statistical techniques employed; the norms retrieved from such a process contribute to enhancing the translation speed (Jiang \& van RijHeyligers, 2008) and the native-like naturalness of the target text (Aston, 1999). In contrast to the traditional orientation to excluding translations from corpus collections (see Baker, 1999), translators today are increasingly encouraged to examine and evaluate source and target texts using tools and techniques developed for the application of machine-readable corpora (Mosavi Miangah, 2006). A coherent corpus, namely, a conceptually "representative" collection of translated texts rather than individual translations is taken as the primary object of study (Baker, 1993). This provides the rationale for linguistic inquiries of translational behaviours represented in the actual use of a target language. It is therefore necessary to adopt an inductively interrogative method based on empirical observation and logical verification rather than intuitive deduction and selective illustration of linguistic choices for translation.

Researchers have justified the use of corpora in translation studies based on the occurrence of certain 'patterns' (see Sinclair, 1991). Translation scholars working with Corpus Linguistics argued that "translated text must have its own characteristic patterning" under constrain of a "fully articulated" source text in another language (Baker, 1999, p.282). A 'pattern' is an "essentially repetition" and can be observed in language use when "words, sounds, rhythms or structures are repeated" (Hunston, 2010, p.152). Patterns demonstrate "the systematic ways in which linguistic features are used in association with other linguistic and non-linguistic features" (Biber, Conrad, \& Reppen, 1998, p.5). Translators would find it easier to analyse and translate linguistic patterns in source texts if they were equipped with basic knowledge of how patterns can be technically identified and pragmatically interpreted. However, it can be difficult for trainee translators (who are not native speakers of the source language) to

\footnotetext{
3 Language users would sometimes intuitively pick up some "patterns", but this relies mainly on "the introspective knowledge of the informed, educated language user who can invent examples for analysis to illustrate certain hunches about language behaviour" (Laviosa 2011, p.137). The intuitive approach, therefore, fails to help researchers make reliable claims on large quantity of empirical language data (Baker 2011, p.20). Corpus approaches, by contrast, enable researchers to easily distinguish between significant and casual collocations using statistical measures (see Laviosa 2011 for details).

4 Toury (2012) differentiates descriptive translation studies and prescriptive translation studies, arguing that the former is in favour of approaches which are about examining existing translational discourse and describing how they are produced or evaluated. This idea, obviously, shares a lot with the way corpus linguists investigate texts on a distributional basis.
} 
identify linguistic patterns by simply observing the language use in source texts, also considering the fact that patterns may occur in different variations. To examine linguistic patterns involves investigating how lexis-evoked frames as units of meaning can help translators to interpret translational discourse.

We can ask at what level(s) translators and researchers can approach linguistic patterns in a corpus of translational texts. A single word as a basic linguistic form can be easily searched in the corpus, since lexis does lend itself well to computer-assisted form identification. The search can be further refined based on the collocational information which implies potential pattern(s) of a word (Hunston, 2010). 'Collocation' conventionally indicates the co-occurrence between linguistic forms in terms of semantic sense (see Hoffmann \& Lehmann, 2000; Sinclair, 1987). The concept of collocation has been used to refer to the patterning phenomena that some lexical words predominantly co-occur with each other within some evaluative discursive structures. In Corpus Linguistics research, the relevant notions of such phenomena include 'semantic preference' and 'semantic prosody'.

Semantic preference refers to "collocation with semantic subsets of different degrees of generality" (Bednarek, 2008, p.129). The co-occurring tendency of words is shared within a certain speech community (Partington, 2004), being context-, genre- and domain-dependent (Hoey, 2003) and constantly interacts with syntactic patterning (Bednarek, 2008). The occurrence of a strong semantic preference of lexical items has a great potential to "prime" (Hoey, 2005; Partington, 2004) specific expectations from language users when they cumulatively encounter the lexis (Bednarek, 2008). A qualified translator as a competent language user "will hold the vast majority of lexical primings in common" (Partington, 2004, p.152). The translator, therefore, is expected to master the knowledge of the "company that words keep" (Firth, 1957, p.6) in the source language, to ensure that the knowledge structure created by such a company is accurately and sufficiently transferred to the target language.

Semantic prosody (Louw, 1993; Xiao \& McEnery, 2006), by contrast, has evaluative attributes and is pragmatically attitudinal (Sinclair, 1996). Central to semantic prosody is human evaluation. The pragmatics fundamental to a linguistic choice in context corresponds to the evaluative meaning (Bublitz, 1995; Hunston, 1995, 2002; Partington, 1998; Stubbs, 1995) derived from the judgment of the value of discourse. Discussions and debates in Corpus Linguistics generate claims concerning how such evaluation can be categorized: the semantic prosody of a linguistic choice can be positive, negative or neutral. Semantic prosody is, however, difficult to observe and describe due to a lack of surface regularity in discourse thus the identification and interpretation can be highly subjective even problematic (Stubbs, 2001). To identify, interpret and reconstruct semantic prosody of lexical items in the source text, therefore, can be one of the greatest challenges in translation practice and training.

\section{The study}

The design of this study shows features of a "collective case study" (Dörnyei, 2007) where a number of cases are studied jointly around a particular entity to investigate a phenomenon (p. 152). In this study, an English-to-Chinese translation task was the research entity, and each of the trainee translators as a participant was taken as a single case. The boundary of each case was clearly defined, while the focused phenomenon in the multiple cases was examined from a global view.

\subsection{Participants and data}

The participants of this study were seven Chinese MA students majoring in 
English-Chinese Translation and Interpretation at a UK university ${ }^{5}$. All the participants were native speakers of Mandarin Chinese and had achieved a first or upper second undergraduate degree in English language in Mainland China. All of them had had limited experience in translation before they were enrolled in the MA programme. Extensive translation training was taken as supplementary to their compulsory modules in their undergraduate study. Only very few of them had ever worked in the field as a supervised trainee translator. As English-language majors in Mainland China, however, they had a working and basically theoretical knowledge of translation. To be accepted as an eligible candidate for the degree, they were required to get a minimum 7.0 overall with 6.5 or above on speaking and writing sub-skills in the International English Language Testing System (IELTS). Participants also had to pass the entrance interview to gain admission into the two-stage (2-year) MA programme in Translating and Interpreting.

The participants were asked to undertake a translation task as the assignment of a compulsory module in their first year, namely, Stage 1. The mark of their translation work was taken as part of the course requirement which would determine the path they would be able to choose to pursue their specialized study in Stage 2. The participants were thus highly motivated. The complete task cycle was the focus of data analysis in this study which covered three parts:

1) The source text (ST) ${ }^{6}$ : in English; 637 tokens $^{7}$ in total; extracted from an editorial published in The Observer ${ }^{8}$ on Sunday, 18 November 2012, covering an analytical prediction of the dire economic consequences of Britain's potential exit from the European Union (EU).

2) The translated texts (TT): seven translated texts; in Chinese; 8676 characters ${ }^{9}$ in total; with mainstream Chinese readers as the intended target audience.

3) The seven reflective commentaries: in English; around 8400 tokens in total; each containing one of the participants' reflection on the problems encountered in the translation process and justification of any solutions based on theoretical and practical evidence. In each reflective commentary, three examples have been provided.

The participants were required to complete the translation task by themselves. They were given maximum six weeks to complete the task and allowed to use any accessible resources (e.g. dictionaries, books, newspapers, websites, etc.) except for web-based translation tools (e.g. Google Translator). In addition, each of them was allowed to consult maximum three informants ${ }^{10}$.

\footnotetext{
${ }^{5}$ The participants were recruited from the chosen university on a voluntary basis using snowballing technique.

${ }^{6}$ See Appendix A for the source text.

${ }^{7}$ If a text is said to have 637 tokens, it is 637 words long. The term is commonly used to calculate type-token ratio (also known as TTR) in linguistics research to examine the lexical density of a particular text. Types, by contrast, refer to the number of different words in a text.

${ }^{8}$ A British newspaper published on Sundays as a sister paper of The Guardian.

${ }^{9}$ Chinese characters are logograms developed for the writing system of Chinese language. A Chinese character almost corresponds to a single syllable that is also a morpheme, namely, the inseparable smallest unit of meaning. While it would be rather difficult to define a 'word' in Chinese, there is close correspondence between 'characters' and 'words' in the language. In modern Chinese, the majority of words consist of two or more characters.

${ }^{10}$ There was no strict restriction on the selection of informants. Professional translators, lecturers in translation in Higher Educational institutions, book writers, correspondents, newspaper editors, or even common native speakers of English were found to be chosen by the participants as their informants.
} 
The informant could provide background knowledge of the source text or help with proofreading but was not allowed to be directly involved in the translation process.

It should be noted that the data size of this study is relatively small, which means that the results may not be generalized to other research contexts. Yet, the sample reflects some generic features of Chinese trainee translators' professional practice at UK universities since the participants showed a great degree of homogeneity in terms of their cultural origin, language proficiency, educational background and learning motivation. The qualitative sampling strategy ${ }^{11}$ helped gather sufficient data which provides rich insights into the proposed research subject in this study. Nevertheless, more empirical data is needed in further research.

\subsection{Automated semantic tagging and the corpus analysis toolkit}

Translators orient to (Drew \& Heritage, 1992) the source text and the translated text by transferring 'meaning' of the former to the latter. Defined with reference to meaning, any linguistic form in the source language is viewed to have its translation in the target language into "some further, alternative sign" (Jakobson, 1959, p.32) which is usually more developed but textually presented in a more explicit manner. It means that the translator is expected to know more about a word in the source text than what a dictionary can tell him/her. The access to the linguistic information of the word at multiple levels is thus necessary. The application of computer software in corpus analysis enables the researcher to re-arrange the way natural language use can be processed thus makes it easily and systematically accessible (Hunston, 2002; Scott, 2010) to achieve different research purposes. Software-based automated semantic tagging, as one of the most widely used Corpus Linguistics techniques, facilitates inquires on knowledge representation and construction by identifying lexical items within unique semantic categories at the discursive level. It serves as "a crude basis of translation per se" (McEnery \& Wilson, 1993, p.5; see also Leech, 1997, p.2) by adding valuable linguistic information to the raw textual data. Therefore, the interrogation of a semantically tagged corpus of translational texts can help the translator strategically involve the schematic dimension of knowledge structures into the sense-based language.

The automated semantic tagging system used in this study is the UCREL Semantic Analysis System $\left(\right.$ USAS $^{12}$ ), developed by Rayson (2002) at Lancaster University, UK. The semantic tagger of USAS "automatically assigns semantic fields (domains) to each word or multiword expression" (Rayson, 2008, p.527) in a corpus. The semantically tagged texts are then analysed using particular Corpus Linguistics software. The authors of the USAS tagging system combine various techniques on semantic tagging and word sense disambiguation (WSD), and classify items according to "a broad semantic taxonomy rather than rather than fine-grained word sense definitions", and assign semantic categories to all words rather than selected classes (Rayson, Archer, Piao, \& McEnery, 2004, p. 2$)^{13}$.

In this study, the translated texts were used to build the TT Corpus and the reflective commentaries were used to build the C Corpus, which contained all the reflective commentaries written by the participants. The computer software

\footnotetext{
11 In Applied Linguistics research, sampling relates mostly to quantitative studies, aiming to produce a sizeable sample to show the representativeness of by getting rid of individual differences (Dörnyei, 2007, p.126). In qualitative studies, by contrast, the main of sampling is "to find individuals who can provide rich and varied insights into the phenomenon under investigation" (p.126). The sampling strategy used in this study can be taken as what is called "homogeneous", through which the participants were selected from a particular subgroup and shared some important experience relevant to the research focus (e.g. nationality, language education background, etc.)

${ }^{12}$ See Appendix B for the full USAS semantic tagset.

${ }^{13}$ See Rayson (2002, p.66) for details of the USAS lexicon and semantic tags.
} 
used for data analysis was AntConc 3.4.4, a free corpus analysis toolkit for text analysis (Anthony, 2014) ${ }^{14}$. The source text, the TT Corpus and the C Corpus were semantically tagged before they were uploaded into AntConc 3.4.4 for further analysis. Searching a particular semantic tag in the source text revealed how frequently a semantic domain is involved for meaning construction. A tagbased frequency list helped to understand the main idea of the source text in terms of the author's lexical choices. Examining the concordance lines (instances of a searched word/expression in context) of a particular semantic domain showed what lexical items were tagged in it and their distribution in a corpus. In addition, concordance lines of particular words in the commentaries were useful to discover patterns of the participants' reflective language use and to further explore why and how the patterns had been formed and reinforced in the cycle of the translation task.

\section{Findings and discussion}

\subsection{Constructed reality in the source text}

News is a selective representation of the world (Schudson, 2003). Much more than getting the target audience "informed", news stories are produced following formulas for mass communication to get the audience "affected" and "involved" through professionally manipulated information representation and circulation. Successful communication between a newspaper article and its audience works within a framework of the audience's assumptions and predictions to arrive at accurate mental representations of the world. The frames to be evoked from the audience are, therefore, highly controlled by the news producer. In this study, the ST is mainly about assumptions and predictions of the negative consequences of Britain's potential exit from the EU. The moral dimension provides structural dynamics for framing to construct the "realities" from the journalist's view. Table 1 shows the top five semantic domains of the ST which are the most relevant to the analytic focus of this study.

Table 1 Top five semantic domains in the ST

\begin{tabular}{|l|l|l|}
\hline Semantic domain & No. of tags & Exemplar words (3) \\
\hline E. Emotional actions, states \& processes & 7 & anxiety, attack, hysterical \\
\hline G. Government \& public domain & 30 & renegade, poll, referendum \\
\hline Q. Linguistic actions, states \& processes & 16 & argument, proposed, media \\
\hline S. Social actions, states \& processes & 45 & defend, collaboration, leaders \\
\hline X. Psychological actions, states \& processes & 28 & believe, distrust, inclined \\
\hline
\end{tabular}

Considering some words are repeatedly used in the ST thus are likely to be tagged in the same semantic domain multiple times, I searched the concordance lines of the top five semantic domains. Table 2 below shows the distribution of the words tagged in the five semantic domains.

Lexical words are most frequently tagged in Domain S. Social actions, states \& processes, most tags of which show a positive position on their semantic scales (indicated by "+"). The concept of "collective identity of the UK citizens' is emphasized (S5. Groups and affiliation), whose 'relationship' (S3.1 Relationship: general) with the EU has been expected to be achieved and sustained through 'collaboration' (S1.1.3+. Positive participation) since the EU constantly shows its 'goodwill' (S.1.2.1+. Approachability and friendliness) and provides necessary 'help' (S8+. Helping) to its member states. The lexical words collaboratively frame the source text based on a conceptual pattern: $W e$ are to be with $X$ because $X$ is good to us. Built upon this pattern is a framing practice at the institutional level concerning how the positive relationship with

${ }^{14}$ See http://www.laurenceanthony.net for details of AntConc corpus analysis toolkit. 
the EU would sustain: We need leaders (S7.1+ Holding power to organize) across the country to exert their influences on the UK's staying within the EU.

Table 2 Words with semantic tags in the ST

\begin{tabular}{|c|c|c|c|c|c|c|c|c|c|c|}
\hline \begin{tabular}{|l|} 
Rank \\
\end{tabular} & Word & Tag & Word & Tag & Word & Tag & Word & Tag & Word & Tag \\
\hline 1 & share & S1.1.2+ & assumption & X2.1 & authonities & G1.1 & manifestos & Q1.2 & hysterical & E1 \\
\hline 2 & collaboration & S1.1.3+ & believe & X2.1 & backbench & G1.1 & argument & Q2.1 & complains & E2- \\
\hline 3 & goodwill & S1.2.1+ & distrust & X2.1 & govemment & G1.1 & speaking out & Q2.1 & attack & E3- \\
\hline 4 & stronger & S1.2.5+ & feeling & X2.1 & parliament & G1.1 & account & Q2.2 & bullied & E3- \\
\hline 5 & strength & S1.2.5+ & intellectuals & X2.1 & states & G1.1 & complains & Q2.2 & appease & E3+ \\
\hline 6 & relationship & S3.1 & no longer trust & X2.1- & Labour & G1.2 & for & Q2.2 & anxiety & E6 \\
\hline 7 & collectively & S5+ & feel & $\mathrm{X} 2.1$ & parties & G1.2 & on & Q2.2 & confident & E6+ \\
\hline 8 & member & S5+ & know & $\mathrm{X} 2.2+$ & political & G1.2 & proposed & Q2.2 & & \\
\hline 9 & members & S5+ & development & $\mathrm{X} 2.4$ & poll & G1.2 & renegotiated & Q2.2 & & \\
\hline 10 & teams & S5+ & research & X2.4 & referendum & G1.2 & suggesting & Q2.2 & & \\
\hline 11 & public & S5+ & scrutiny & X2.4 & renegade & G1.2 & media & Q4 & & \\
\hline 12 & need & S6+ & silent & X3.2- & Tory/Tories & G1.2 & & & & \\
\hline 13 & obliged & S6+ & see & X3.4 & trade & G1.2 & & & & \\
\hline 14 & compelled & S7.1+ & principle & $\mathrm{X} 4.1$ & Ukip & G1.2 & & & & \\
\hline 15 & directors & S7.1+ & tactical & $\mathrm{X} 4.2$ & union & G1.2 & & & & \\
\hline 16 & leaders & S7.1+ & losing heart & X5.2- & opportunistic & G2.2 & & & & \\
\hline 17 & leadership & S7.1+ & interest & X5.2+ & & & & & & \\
\hline 18 & managing & S7.1+ & choice & X7+ & & & & & & \\
\hline 19 & co-ordination & S7.1+ & inclined & X7+ & & & & & & \\
\hline 20 & power & S7.1+ & policy & X7+ & & & & & & \\
\hline 21 & powers & S7.1+ & strategy & $\mathbf{X 7 +}$ & & & & & & \\
\hline 22 & directors & S7.1+ & trying & $\mathrm{X8+}$ & & & & & & \\
\hline 23 & sovereignty & S7.1+ & able & X9.1+ & & & & & & \\
\hline 24 & veto & S7.4- & overwhelming & X9.2+ & & & & & & \\
\hline 25 & concessions & S7.4+ & win & X9.2+ & & & & & & \\
\hline 26 & defend & S8+ & & & & & & & & \\
\hline 27 & favour & S8+ & & & & & & & & \\
\hline 28 & bail-out & S8+ & & & & & & & & \\
\hline 29 & part & S8+ & & & & & & & & \\
\hline 30 & playing & S8+ & & & & & & & & \\
\hline 31 & rescue & S8+ & & & & & & & & \\
\hline
\end{tabular}

The framing is practiced through "reconstituting the motivating circumstances" (Fillmore, 1982, p.387) of a familiar scene by reinforcing the power relationship within the country to address a specific problem such as Britain's possible exit from the EU. The textual preference is revealed from the explicit references to the UK's political parties (G. Government and public domain) and an articulate gloomy prediction about the result of any referendum. The existing circumstances in the UK are the testimony to such a prediction, manifested by the mutual distrust and disappointment between the UK and the EU (X2.1. Thought, belief; X5.2-. Losing interest). Lexical words denoting 'uncertainty and struggle' (e.g. assumption, feeling, argument, opportunistic, proposed, suggesting) and 'negative emotions' (e.g. hysterical, complain, attack, bullied, anxiety) are frequently used, representing a semantic prosody featuring a negative attitudinal evaluation of what is happening and likely to happen to the UK-EU relationship.

The ST author's losing faith in a referendum and advocating resolute leadership conceptually discriminate in favour of the UK social elite ("the best in Britain"), which would deepen the inequality of participation in the country's political affairs. This stance might make the use of we quite ambivalent for the translator to interpret. One way to look at the choice of the referential pronoun is to take it as a claim for a wider national solidarity. We in such sense is used inclusively (Fairclough, 1989) to refer to all the UK citizens (other than merely the middle class) since Britain's economic survival is a big public concern which demands more solidarity than disputes to decide the country's fate. The low frequency of 'we' in the ST (2 hits), however, challenges this assumption. That 'Britain' is used much more frequently (10 hits) than 'we' suggests a conceptual distance created and kept from the people with inferior social status 
in the country who thus have less political power. While the use of we seems to be "relationally significant" (Fairclough, 1989, p.189), it potentially manifests an exclusive orientation. The collaboration appealed for, therefore, is selective and the 'reality' is actually 'constructed' rather than being 'reflected' through the author's strategic framing. To summarize, the cognitive frame evoked by the ST is a [LED STAY] ${ }^{15}$ one: Britain is obliged to STAY within the EU for its economic security which serves best the UK elite's interest; thus the 'staying campaign' has to be launched by socio-political LEADERS rather than through a referendum.

\subsection{Framing in translation}

To the majority of British citizens, the communication between a newspaper article such as the source text and the target audience would be typical because of their shared cultural and linguistic background. With only "minimal" alternation of their mental structures (Cook, 1989, p.74), native speakers of English can easily make sense of the text regarding any new information. To the target audience of the translated text, however, such alternation is not to be readily activated since the presupposed schematization of interpretative judgment (Fillmore, 1982) of UK readers is not necessarily available to nonUK readers. The schematization is a result of a complex interaction of the social institutions and structures of human experience (Fillmore, 1982) within a certain cultural community. Considering the length limitation of this article, I shall analyse and discuss three examples to show how schematic knowledge transfer was managed by the trainee translators through their framing practice in the translation task.

\subsubsection{Semantic preference and prosody: 'renegade'}

The word 'renegade' first appears in the lead of the ST and once again in the body text. The lead reads: "If Britain leaves Europe, we will become a renegade without economic power". How to translate 'renegade' is no doubt of great importance, since it implies the keynote of the ST. The Collins COBUILD dictionary ${ }^{16}$ defines 'renegade' as "a person who abandons the religious, political, or philosophical beliefs that he or she used to have, and accepts opposing or different beliefs".

'Renegade' is perceived as a relational noun, the interpretation of whose meaning relies on verifying its relations to other entities (Asmuth \& Gentner, 2005). Relational nouns are "linguistically constructed" (Gentner \& Kurtz, 2005, p.156), showing greater sensitivity to context (Kersten \& Earles, 2004) thus can cause conceptual gaps in translation practice. Within the frame evoked by renegade, three entities are involved: a person, his/her previous belief/group, and his/her new belief/group. The relational structure is 'the person DESERTS what he/she used to belong to or believe in and TURNS to something DIFFERENT or even OPPOSING'. A search result of renegade in the British National Corpus (BNC) shows that the actual use of the word in the corpus features a semantic preference of the [DESERTING] choice from a certain organization or faith. Particular linguistic patterns in accordance with the semantic preference become salient in spite of a lack of surface colligational regularity. The concordance lines of renegade further suggest a semantic prosody of [DISAPPROVAL], which is evident in most of the instances. A qualified translation is therefore expected to be located somewhere along the semantic-pragmatic continuum (Sinclair, 1996) to seek a directional equivalence (Pym, 2007) of 'renegade'. The process concerns creative language

\footnotetext{
${ }^{15}$ Frames in this article are presented with small uppercase letters in square brackets and frame elements are presented with uppercase letters.

16 The Collins COBUILD dictionary is compiled based on the linguistic information in the Collins corpus, an analytical database of English with over 4.5 billion words. See https://collins.co.uk/pages/elt-cobuild-reference for details of the Collins COBUILD dictionaries.
} 
use to reconstruct the semantically relational pattern of the word. Figure 1 shows the participants' translations of the news lead. Table 3 shows the translations and back translations ${ }^{17}$ of the word 'renegade'.

$\pi 1$ : 如果离开欧盟, 英国将成为一个没有经济实力的叛徒

TT2: 如果退出欧盟, 英国将沦为失去经济势力的边缘者

Tा3: 脱离欧盟一旦成真, 英国经济实力将不复存在

T4: 若离开欧盟, 英国或成为无经济实力的叛变者

TT5: 如果英国退出欧盟, 我们定将成为丧失经济力量的逃兵

Tा6: 退出欧盟, 英国将沦为毫无经济实力的叛徒

TT7: 英国退出欧盟, 改弦易辙实属不易

Figure 1 Translations of the news lead

Table 3 Translations and back-translations of 'renegade'

\begin{tabular}{|l|l|l|}
\hline TT No. & Translation (Chinese) & Back translation (English) \\
\hline TT1 & 叛徒 & 'traitor' \\
\hline TT2 & 边缘者 & a marginalized person \\
\hline TT3 & no direct equivalent & N/A \\
\hline TT4 & 叛变者 & 'traitor' \\
\hline TT5 & 逃兵 & 'deserter' \\
\hline TT6 & 叛徒 & 'traitor' \\
\hline TT7 & no direct equivalent & N/A \\
\hline
\end{tabular}

Table 3 demonstrates that even operating at the semantic level, the participants tended to invoke different frames based on what had been evoked by renegade. The translators of TT1, TT4 and TT6 used the same Chinese word 叛徒 (which means 'traitor') as the equivalent of renegade. This translation is seen as favourable since it succeeds transferring what has been framed by 'renegade' with the two core semantic elements accurately addressed: the meaning of [DESERTING] for its semantic preference and the function of [DISAPPROVAL] for its semantic prosody. The word 叛徒, however, semantically limits the scope of the 'meaning potentials' for 'renegade' since it emphasizes the OPPOSING rather than the DIFFERENT properties of what the person has turned to believe or take part in. It results in the translated texts being framed with a more negative attitudinal evaluation to the target audience but has to a large extent retains the original framing.

Other translations, however, only partially attended to the frame evoked by 'renegade'. For example, the translator of TT2 translated 'renegade' into 边缘 者 which means 'a person who is marginalized by some form of force'. This translation, if not irrelevant at all, misinterprets the frame supposed to be evoked but invokes another frame for the target audience: Britain's exit from the EU is the result of some external force rather than its own will. In addition, the

17 Back translations in this article refer to the translations (in English) of the participants' translations (in Chinese) of the source text. 
evaluative standpoint of this translation has been mysteriously shifted from Britain to another entity, especially to its institutional boundary across which Britain is expected to be approaching. Similarly, the translator of TT5 translated 'renegade' into 逃兵 which means 'deserter'. This translation, while not as inaccurate as 边缘者 and indeed expressing the meaning of [DESERTING], only addresses the functionally negative connotation of renegade but overlooks the semantic subtlety of the word. A deserter is usually described as someone who leaves their job in the armed forces without permission, while such 'leaving' means nothing more than 'leaving and no turning back'. 'Renegade', by contrast, means that the person leaves and joins another group which is highly likely to work against the former.

How the translators of TT3 and TT7 translated the word 'renegade' was even more deviant from the frame evoked in the ST. They used no direct equivalent of the word in their translations. The invisibility of the meaning of 'renegade' in TT3 might be due to the translator's framing focus shifting to the economic security of Britain as a result of its exit from the EU. Such a shift of focus is shared by the translator of TT7 where she deliberately domesticated the meaning of 'renegade' using a Chinese idiom 改弦易辙 which means 'changing the way of doing things'. The effect of this strategy, when viewed from the perspective of framing, might be destructive to the audience's interpretation since it sees both the semantic and pragmatic meanings of renegade almost disappearing in the translated text. In addition, the idiom is more frequently used in professional news reports, for instance, to describe events of political change, or change of relationship between two countries. This means that its potential to evoke corresponding frames would be to a large extent limited to the particular text type but not readily accessible to a wide readership.

\subsubsection{Metaphorical mappings: 'shadow' and 'thin reed'}

Metaphors have structures in which an abstract concept is "fathomed in terms of a concrete concept" (Hamawand, 2016, p.86). A concept can be metaphorically mapped onto another across domains in different ways. A mapping can project part of the structure of the source domain onto the target domain, by which people use the structure of the former and the corresponding vocabulary to talk about and think about the latter. A mapping can also be built up pragmatically with two relevant domains mapped onto each other when they typically correspond to two categories of objects (Fauconnier, 1998, pp.1-33). Mappings, at a higher cognitive level, are used to structure a situation in context with one or more frames involved (Fauconnier, 1998). Cases of metaphorical mappings were found in the source text in this study, among which I elaborated on two examples: 'shadow' and 'thin reed'.

The sentence in the ST with the word 'shadow' in it reads: "Our fiscal and monetary policy will shadow that of the European authorities for fear of an attack on sterling if we do not" (source text, paragraph 5). 'Shadow' is defined in the Collins COBUILD dictionary as "to follow someone very CLOSELY and especially SECRETLY so that the follower can ACCOMPANY and OBSERVE the followed in a professional setting". Two related frames are expected to be evoked: [FOLLOW] and [COMPLY]. The use of the word reveals a metaphorical mapping projected from the domain of optical image to the domain of object motion. Five of the seven trainee translators translated 'shadow' into 跟随/紧随/尾随 ${ }^{18}$ which means 'to follow (closely)' and another translated it into 与...保持一致 which means 'to conform to'. These translations, however, invoke only one of the two frames evoked, either [FOLLOWING] or [COMPLY]. The translator of TT3 was the only one who

18 Note that 尾随 projects a negative connotation of the action of 'following' in Chinese. A word with a similar semantic prosody in English is stalk. 
succeeded in reconstructing the original meaning of the word by translating it into 默默地参照which means 'follow and comply with some rules secretly'. In addition, the surrounding discourse provides clues of semantic coherence for an accurate translation. The prepositional phrase 'for fear of' not only leads to the reason why Britain will follow the EU fiscal and monetary policy but also indicates that this act is non-voluntary. A quick search in BNC confirms that 'for fear of' has a strong negative semantic prosody, embedded in the pattern "unwillingness (of performing a particular action) + for fear of + unpleasant consequence". The translators of TT2 and TT3 addressed the contextual clue, but chose not to do a direct translation by translating 'for fear of' into 英国害 怕（英镑将会受到攻击) ("because they are frightened (that there would be an attack on sterling'). Instead, they highlighted the "unwillingness" of following, translating 'for fear of' into 不得不and 都得 (both of which mean 'have to').

A broader range of variation has been found in the participants' translations of 'thin reed' (source text, para. 2). The sentence with the expression in it reads: "On that thin reed, dependent on the goodwill of European states who no longer trust Britain's interest in building Europe, hangs our European future." The frame of [FRAGILE SUPPORT] is evoked by 'thin reed' with negative evaluative attributes. A search of 'thin reed' in BNC, however, returns only one instance with no figurative meaning attached, and a query of the collocates of 'reed' reveals no analysable results. The difficulty in identifying surface linguistic patterns in BNC may be due to the fact that the figurative expression "thin reed" ${ }^{19}$ is very old in origin and, therefore, appears to be extremely infrequent in a corpus of present-day, general English. The expression 'On that thin reed, ... hangs our European future' is a mixed metaphor ${ }^{20}$ (see Sullivan 2018). The respective metaphors are "to rest on a slender reed" and "to hang by a slender thread": the first describes a misplaced trust or reliance, and the second describes a precarious position or situation. A comparable mixed metaphor in Chinese can be 摇摇欲荫 ${ }^{21}$, meaning “on the edge of collapse". It describes both a misplaced reliance on something negative (e.g. a sick body, an oppressive reign, an obsolete belief, etc) and a precarious situation once the reliance breaks. The metaphorical mapping projected from the source domain of natural things to the target domain of abstract relations and situations concerns a subtle transfer of the properties of certain relational structures.

The participants' frame-invoking moves around the concept of 'thin reed' interestingly, are found to land along the pragmatic spectrum. One translator literally translated 'thin reed' into 纤薄的苇杆 (TT1, 'thin reed'). Another two focused on the frame element FRAGILITY, translating it into 摇摇欲芏 (TT5, 'on the edge of collapse') and 十分脆弱 (TT6, 'quite fragile'), attending to the core meaning of the frame. Translators of TT2 and TT6 attached evaluative attributes to their translations: 前景堪忧 (TT6, 'with a gloomy outlook on the future') and (英国) 很难掌握自己的未来 (TT2, 'Britain's losing control of its future'). What is particularly curious is that the translators of TT3 and TT7, while sharing the idea that the rhetorical meaning should be completely removed to achieve explicitness and simplification, ended up

19 'Thin reed' (along with 'slender reed', 'slim reed', 'broken reed', etc) dates back at least to the Old Testament, meaning 'flimsy/fragile support' (see https://biblehub.com/ nasb/ isaiah/36-6.htm for examples of 'reed' in the Old Testament).

20 I follow most linguists and psychologists' definition of a mixed metaphor: a metaphor which involves two (or more) respective metaphors that are different from each other and used together within a sentence, clause or other discourse unit (see Lakoff and Johnson, 2003; Sullivan 2018).

${ }^{21}$ 摇摇欲砝 too is old in origin, dating back to The Romance of Three Kingdoms (《三 国演义》, authored by Luo Guanzhong during the fourteenth century, during the Yuan and Ming periods of ancient China), but is used highly frequently in modern Mandarin Chinese. 
invoking contrastive frames in their translations. The translator of TT3 treated the claim that the UK future "hangs on that thin reed" as a fact that Britain has no choice but can only depend on the EU's goodwill (TT3, 这是我们与欧洲 能有良好未来的唯一希望, 'This [the offer of the referendum on a renegotiated relationship with more powers ceded to Britain] is the only way of establishing a good UK-EU relation.'). By contrast, the translator of TT7 tended to interpret it as a hint that Britain can no longer depend on the EU since the latter has almost lost heart in the former's interest in building Europe (TT7, 英 国的欧盟未来已无法寄希望于其他成员国, “The future of Britain cannot depend on other EU members.'). The 'contrastive framings' (Pan, 2017) demonstrate what some researchers call by 'multiple contexts' (see Goodwin \& Goodwin, 1992) where two competing context spaces (Linell, 1998, p.152) are conceptually created, which makes the text open to multiple interpretations.

\subsection{Inquiry into reflective commentaries}

Corpus-based translator training has been widely used to "encourage trainee translators to become critical thinkers and researchers in their own right" (Laviosa 2011, p.145). Critical thinking and research skills in translation needs evaluation of both translated texts and the translation process itself, while the reflection on the latter is far from sufficient and systematic. The purpose of the inquiry into the participants' reflective commentaries is to seek evidence of their language awareness of particular lexical choices and strategy uses. I shall demonstrate in this section how sorted concordance lines of semantically tagged texts in the $\mathrm{C}$ corpus can be used to reveal patterns of the participants' reflective language use. The structures of such language in use are believed to be closely related to the task nature and the trainee translators' professional identity in the translation practice.

Among the top 25 most frequent words in the C corpus (Figure 2), 'I' and 'be' stood out, with any semantic tags, articles, conjunctions and prepositions excluded from the focus. The reason why 'I' and 'be' perform the discursive signposts to direct further inquiry is that ' $\mathrm{I}$ ' is the subject of cognitive reflection and 'be' concerns textual modalities which may be characteristically related to the task nature. The second volume in Figure 2 shows the absolute frequency values of the words. The word 'be' occurs 74 times in the 7 texts while the value 153 for $i$ sums up the frequency of 'I' used as the singular first person pronoun and that of all the tags in the semantic Domain I. Money \& Commerce. Thus, the analysis only focused on the occurrences of 'I' in the first case. Figure 3 shows the concordance lines of 'I'. The semantic tag(s) of a word is (are) marked by an underscore "_" on its right.

A convenient finding suggests that $I$ as a nominative-marked subject immediately proceeds a verb. The verbs show a morphological uniformity in past tense, which indicates that the $\mathrm{C}$ Corpus consists of retrospective reflection rather than on-line progressive reports. The majority (70 out 101) of the 'I' hits are followed by words tagged in three semantic domains:

A. General \& Abstract terms (39 hits);

X. Psychological actions, states \& processes (20 hits); and

Q. Linguistic actions, states $\&$ processes (11 hits).

Words tagged in Domain A see the largest within-domain variation. Two related frames stand out as prototypical concerning the participants' lexical choices for reflection: [FINDING AND EVALUATION] evoked by words tagged in sub-domain A5, and [ACOORDING ACTION] evoked by words tagged in sub-domain A1. Words tagged in sub-domain A1 are more frequently used than those in A5, which suggests that the reflection is mainly action-based involving a series of related moves which are linguistically represented through the use of general verbs such as make, keep, divide, adopt, get, use, put, etc. 
Words tagged in Domain X help the participants draw their mental paths throughout the translation process thus highlight the cognitive attributes to their decisions and strategy uses. Two related frames stand out: [NOTICING AND THINKING] evoked by words tagged in sub-domains X3 and X2, and [CHOOSING AND TRYING] evoked by words tagged in sub-domains X7 and $\mathrm{X} 8$. A closer look at the concordance lines of the words used in Domain X reveals that cognitive struggles and mental activities at higher levels occurred when interpretative obstacles and translational challenges were identified. Lastly, words tagged in Domain Q (mainly sub-domains Q2 and Q3) concern the participants' strategy uses at the textual / inter-textual level, including ana-

\begin{tabular}{|c|c|c|}
\hline Rank & Freq & Word \\
\hline 1 & 9481 & punc \\
\hline 2 & 3288 & $z$ \\
\hline 3 & 1408 & $a$ \\
\hline 4 & 701 & $q$ \\
\hline 5 & 451 & the \\
\hline 6 & 398 & $n$ \\
\hline 7 & 398 & $x$ \\
\hline 8 & 358 & s \\
\hline 9 & 279 & $\mathrm{~m}$ \\
\hline 10 & 275 & $\mathrm{mf}$ \\
\hline 11 & 217 & to \\
\hline 12 & 198 & of \\
\hline 13 & 173 & in \\
\hline 14 & 171 & and \\
\hline 15 & 171 & is \\
\hline 16 & 153 & \\
\hline 17 & 134 & $\mathrm{t}$ \\
\hline 18 & 84 & as \\
\hline 19 & 81 & C \\
\hline 20 & 77 & that \\
\hline 21 & 76 & $\mathrm{~g}$ \\
\hline 22 & 74 & \\
\hline 23 & 71 & this \\
\hline 24 & 67 & 的 \\
\hline 25 & 65 & it \\
\hline
\end{tabular}

Figure 2 Top 25 single words in C corpus

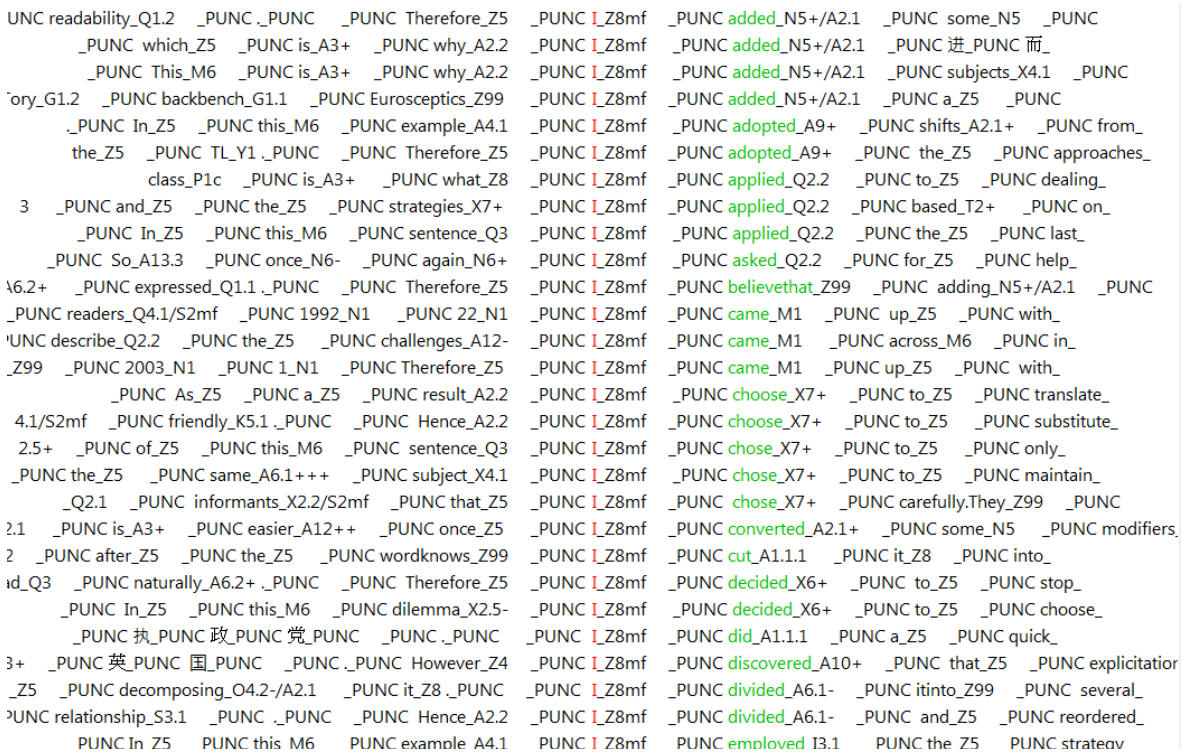

Figure 3 Sorted concordance lines of ' $I$ ' 
phoric reference (e.g. "refer back to"), explication of rhetorical lexis (e.g. "paraphrase this metaphor") and seeking external assistance (e.g. "ask for help from informants").

Words used with 'be' show a syntactic uniformity with all the relevant sentences in a passive voice. That 'be' is overwhelmingly used with modal verbs (60 out of 74 hits) is another feature worth noticing. Figure 4 shows the sorted concordance lines of 'be', among which the modal verbs can, should and will/would are most frequently co-selected. The three modal verbs evoke corresponding frames of modality: [POSSIBILITY], [OBLIGATION] and [PREDICTION]. A closer look at the concordance lines reveals unique language patterns (Table 4), indicating that the participants' reflective commentaries were textually structured and represented along the continuum of modality. They seemed to be most certain of their interrogative logic to make sense of the source language and culture, while not confident enough about their strategy uses in the translation process. Their recollection and evaluation of the source text, partially dependent on their interpretative framings, are placed in the middle of the modality spectrum.

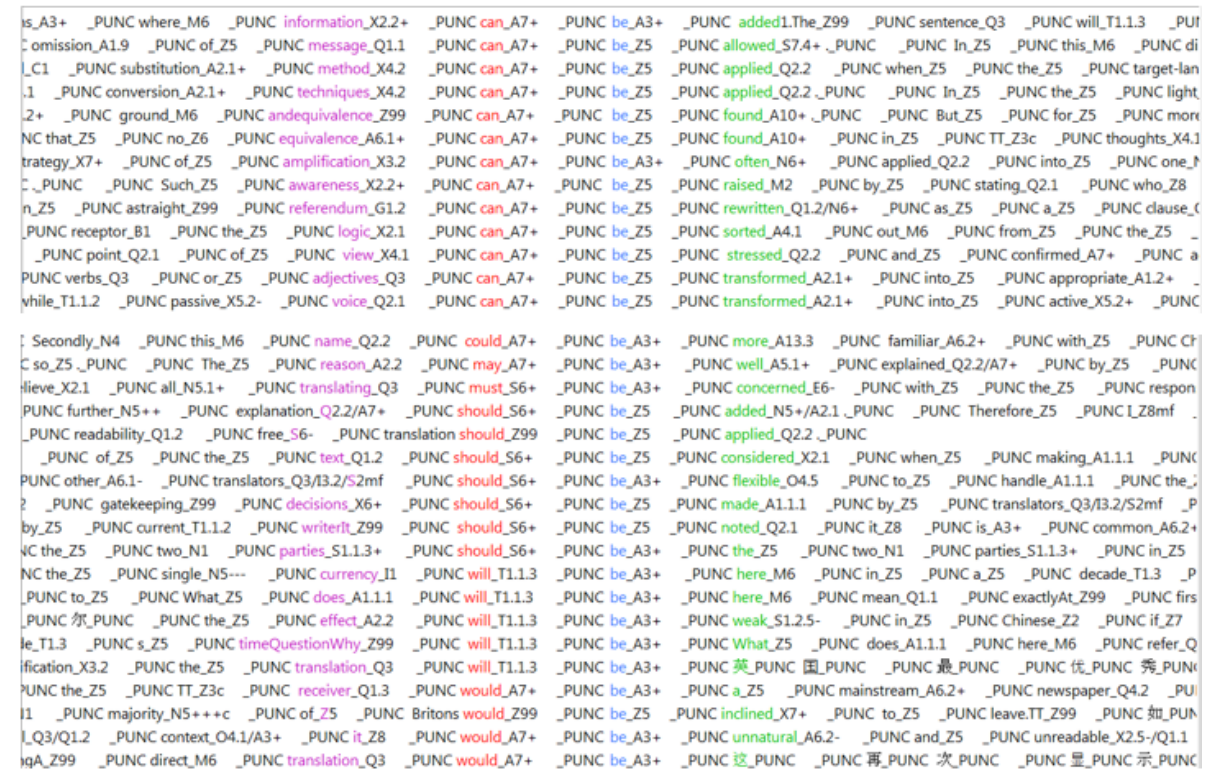

Figure 4 Sorted concordance lines of 'be'

Table 4 Patterns of modal verbs with 'be'

\begin{tabular}{|l|l|}
\hline Pattern & Example \\
\hline $\begin{array}{l}\text { concrete translation strategy+ } \\
\text { 'can'+ 'be' + verbs featuring } \\
\text { general actions }\end{array}$ & $\begin{array}{l}\text { "information can be added"; "message can be allowed"; } \\
\text { "conversation techniques can be applied"; "equivalence } \\
\text { can be found"; "the logic can be sorted"; "voice can be } \\
\text { transformed", etc. }\end{array}$ \\
\hline $\begin{array}{l}\text { fact/situation + 'should' + 'be' + } \\
\text { verbs featuring psychological } \\
\text { actions or processes }\end{array}$ & $\begin{array}{l}\text { "decisions should be made"; "it should be noted..."; } \\
\text { "translators should be flexible"; "the purpose of the text } \\
\text { should be considered", etc. }\end{array}$ \\
\hline $\begin{array}{l}\text { Within/inter-textual entities/events } \\
+ \text { 'will/would' + 'be' + verbs } \\
\text { featuring recollection or evaluation }\end{array}$ & $\begin{array}{l}\text { "single currency will be here"; "effect will be weak"; } \\
\text { "the receiver would be a mainstream newspaper"; "the } \\
\text { translation would be..."; "(the context) it would be } \\
\text { unnatural", etc. }\end{array}$ \\
\hline
\end{tabular}

To summarize, language patterns in the participants' reflective commentaries are closely related to the task nature: it is retrospective, actionbased and expressively tentative. The former two features correspond to the task specifics that the participants were required to write the commentary after 
completing the translation. The tentative tone in their textual expressions, however, reveals the participants' professional identity at a unique transitory stage to become professional translators. They collectively showed a deficiency of self-confidence about the legitimacy and validity of their translational decisions, which has been demonstrated by their repeated uses of hedging devices in their commentaries. The findings also suggest that the translator's self-commentary is a valuable data source for the trainer/researcher to explore how and why certain translation strategies are used and evaluated and what cognitive activities are involved in such processes so that the mentality of trainee translators can be characterized, and their needs met.

\section{Concluding remarks}

The research findings of this study suggest that frames as schematized, experience-based and context-sensitive knowledge structures are crucial units of meaning to interrogate both source texts and translated texts in translation studies. Lexical concepts can be legitimately taken as an analytic dimension of translational data. The cognitive frames supposed to be evoked by certain lexical words in the source text in this study, however, are not sufficiently activated or accurately interpreted by most of the participants, which leads to distortion of meaning (to some extent) and contrastive framings in their translations. More serious deviation has been found from the original meaning of some frame elements in the source text when the participants dealt with conceptual structures involving metaphorical mappings. Analysis of the reflective commentaries indicates that the general features of their reflective language use are closely related to the task nature. The trainee translators' professional identity has been explicitly represented through the patterns of their reflective language use.

The research findings also suggest that Corpus Linguistics approaches show strong technical advantages to systematically identify, describe and interpret linguistic patterns in translation as a unique type of text production. Sense-based semantic tagging techniques can be applied to identify frames and to differentiate frame elements with contrastive meanings, thus are useful to conduct comparative analyses between the source text and the translated text. Notions of 'semantic preference' and 'semantic prosody' are of particular theoretical relevance to the investigation of linguistic patterns in translational texts. Sorted concordance lines provide a powerful way of searching, examining, and characterizing certain part of the text when no surface regularity can be easily identified through manual observation.

This study has significant implications for translator training. First, it advocates a systematic view to see each translation task as a complete procedural cycle where the translator starts from interrogating the source text, creates the translation by reconstructing meaning, recalls significant challenges, and improves the translation through an explicit, critical evaluation. Second, it emphasizes that translation, while can be highly individualized, is by no means an isolated practice. Instead of focusing solely on one translated text of a particular source text, trainers are encouraged to collect data of multiple translated texts of the same source text, with the inquiry parameters well controlled and explicated. Finally, Frame Semantics and Corpus Linguistics approaches can be effectively combined to benefit guided translational text analysis among trainee translators. Specifically, the creation, application and evaluation of translator training programmes should focus on the expansion of the scope of cognitive and textual space. This would help to liberate trainee translators from deliberately attending to the aspects of formal correspondence at high levels of abstraction (see Catford, 1965). A more developed translator training course should provide trainee translators with a broader range of 
available linguistic resources with schematic correspondence and contextual relevance. It calls for a pedagogical shift in translators training: instead of teaching how to search for an equivalent of certain lexical items in the source text, the trainer is expected to address the complexity and diversity involved in their 'meaning potentials'. In such way, trainee translators can be well facilitated to interpret lexical items in a situated way and at multiple levels (Rojo López, 2002), so as to optimize their application of linguistic resources in translation practice.

\section{References}

Allwood, J. (2003). Meaning potentials and context: Some consequences for the analysis of variation in meaning. In H. Cuyckens, R. Dirven, \& J. Taylor (Eds.), Cognitive approaches to lexical semantics (pp. 29-66). Berlin, Germany: Moutonde Gruyter.

Anthony, L. (2014). AntConc (Version 3.4.3) [Computer Software]. Tokyo, Japan: Waseda University. Retrieved from http://www.laurenceanthony.net

Asmuth, J., \& Gentner, D. (2005). Context sensitivity of relational nouns. Paper presented at Proceedings of the twenty-seventh annual meeting of the cognitive science society, pp. 163-168.

Aston, G. (1999). Corpus use and learning to translate. Textus, 12, 289-314.

Bäckström, L., Lyngfelt, B., \& Sköldberg, E. (2014). Towards interlingual constructicography: On the correspondence between construction resources for English and Swedish. Constructions and Frames, 2(1), 9-33.

Baker, M. (1993). Corpus Linguistics and Translation Studies: Implications and Applications. In M. Baker, G. Francis, \& E. Tognini-Bonelli (Eds.), Text and technology: In honour of John Sinclair (pp. 233-250). Philadelphia: John Benjamins.

Baker, M. (1999). The role of corpora in investigating the linguistic behaviour of professional translators. International Journal of Corpus Linguistics, 4(2), 281298.

Baker, M. (2004). A corpus-based view of similarity and difference in translation. International Journal of Corpus Linguistics, 9(2), pp. 167-193.

Baker, P. (2011). Social involvement in corpus studies. In V. Viana, S. Zyngier \& G. Barnbrook (Eds.), Perspectives on Corpus Linguistics (pp. 17-27). Amsterdam/Philadelphia: John Benjamins.

Baker, P., Hardie, A., \& McEnery, T. (2006). A glossary of Corpus Linguistics. Edinburgh, Scotland: Edinburgh University Press.

Basili, R., Cao, D. D., Croce, D., Coppola, B., \& Moschitti, A. (2009). Cross-language frame semantics transfer in bilingual corpora. Computational Linguistics and Intelligent Text Processing, 10th International Conference, CICLing 2009, Mexico City, Mexico, March 1-7, 2009. Proceedings. DBLP.

Bateson, G. (1972). Steps to an ecology of mind. New York: Ballantine Books.

Bednarek, M. (2005). Frames revisited - the coherence-inducing function of frames. Journal of Pragmatics, 37, 685-705.

Bednarek, M. (2008). Semantic preference and semantic prosody re-examined. Corpus Linguistics and Linguistic Theory, 4(2), 119-139.

Biber, D., Conrad, S., \& Reppen, R. (1998). Corpus linguistics: Investigating language structure and use. Cambridge, England: Cambridge University Press.

Boni, F. (2002). Framing media masculinities: Men's lifestyle magazines and the biopolitics of the male body. European Journal of Communication, 17, 465-478.

Brinton, L. J. (2000). The structure of modern English: a linguistic introduction. Amsterdam/Philadelphia: John Benjamins.

Bublitz, W. (1995). Semantic prosody and cohesive company: Somewhat predictable. General and Theoretical Papers 347, 1-23. Duisburg: L.A.U.D. (Linguistic Agency University of Duisburg).

Carragee, K.M., \& Roefs, W. (2004). The neglect of power in recent framing research. Journal of communication, 54(2), 214-233.

Catford, J. C. (1965). A linguistic theory of translation (Vol. 31). London, England: Oxford University Press. 
Clausner, T. C., \& Croft, W. (1999). Domains and image schemas. Cognitive Linguistics, 10, 1-32.

Coleman, C. L., \& Dysart, E. V. (2005). Framing of Kennewick Man against the backdrop of a scientific and cultural controversy. Science Communication, 27(1), $1-24$.

Cook, G. (1989). Discourse. Oxford, England: Oxford University Press.

Čulo, O. (2013). Constructions-and-frames analysis of translations: The interplay of syntax and semantics in translation between English and German. Constructions and Frames, 5(2), 143-167.

Darwish, A. (2006). Translating the news: Reframing constructed realities. Translation Watch Quarterly, 2(1), 52-94.

Dörnyei, Z. (2007). Research methods in Applied Linguistics: Quantitative, qualitative, and mixed methodologies. Oxford, England: Oxford University Press.

Drake, L. E., and Donohue, W. A. (1996). Communication framing theory in conflict resolution. Communication Research, 23(3), 297-322.

Drew, P., \& Heritage, J. (1992). Talk at work: Interaction in institutional settings. Cambridge, England: Cambridge University Press.

Entman, R. M. (1993). Framing: Toward clarification of a fractured paradigm. Journal of Communication, 43, 51-58.

Esser, F. E., \& D'Angelo, P. (2003). Framing the press and the publicity process: A content analysis of meta-coverage in campaign 2000 network news. American Behavioral Scientist, 46, 617-641.

Evans, V. (2006). Lexical concepts, cognitive models, and meaning construction. Cognitive Linguistics, 17(4), 491-534.

Evans, V. (2009). How Words Mean: Lexical Concepts, Cognitive Models, and Meaning Construction. Oxford, England: Oxford University Press.

Fairclough, N. (1989). Language and power. London, England: Longman.

Fauconnier, G. (1997). Mappings in thought and language. Cambridge, England: Cambridge University Press.

Fillmore, C. J. (1982). Frame semantics. In D. Geeraerts, R. Dirren, \& J. R. Taylor (Eds.), Cognitive linguistics: Basic readings (pp. 373-400). Berlin, Germany; New York: Monton de Gruyter.

Firth, J. R. (1957). Papers in linguistics. Oxford, England: Oxford University Press.

Firth, J. R. (1968). Linguistics and translation. In F. R. Palmer (Ed.), Selected papers of J. R. Firth 1952-59 (pp. 84-95). London, England: Longman.

Fung, P., Chen, B., \& Bay, C. W. (2006). Robust Word Sense Translation by EM Learning of Frame Semantics Abstract. Coling/acl on Main Conference Poster Sessions. Association for Computational Linguistics.

Gärdenfors, P. (2014). The geometry of meaning: Semantics based on conceptual spaces. Cambridge, Massachusetts: MIT Press.

Gass, S. (1997). Input, interaction, and the second language learner. Mahwah NJ: Lawrence Erlbaum Associate.

Gentner, D., \& Kurtz, K. J. (2005). Relational categories. In W. K. Ahn, R. L. Goldstone, B. C. Love, A. B. Markman, \& P. W. Wolff (Eds.), Categorization inside and outside the lab (pp. 151-175). Washington, DC: American Psychological Association.

Goffman, E. (1974/1986). Frame analysis: An essay on the organization of experience. New York: Harper Colophon Books.

Goodwin, C., \& Goodwin, M. H. (1992). Context, activity and participation. In P. Auer \& A. di Luzio (Eds.), The contextualization of language (pp. 77-99). Amsterdam: John Benjamins.

Granger, S., Lerot, J., \& Petch-Tyson, S. (Eds.). (2003). Corpus-based approaches to Contrastive Linguistics and Translation Studies. Amsterdam: Rodopi.

Hamawand, Z. (2016). Semantics: A cognitive account of linguistic meaning. Sheffield: Equinox Publishing.

Hasegawa, Y., Lee-Goldman, R., \& Fillmore, C. J. (2014). On the universality of frames: evidence from English-to-Japanese translation. Constructions and Frames, 6(2), 170-201.

Hedegaard, S., \& Simonsen, J. G. (2011). Lost in translation: authorship attribution using frame semantics. Meeting of the Association for Computational Linguistics: Human Language Technologies: Short Papers. Association for Computational Linguistics. 
Hoey, M. (2003). Lexical priming and the properties of text. Retrieved from: http://www.monabaker.com/tsresources/LexicalPrimingandthePropertiesofText.h tm.

Hoey, M. (2005). Lexical priming: A new theory of words and language. London, England: Routledge.

Hoffmann, S., \& Lehmann, H. M. (2000). Collocational evidence from the British National Corpus. In J. K. Kirk (Ed.), Corpora galore: Analyses and techniques in describing English (pp. 17-32). Amsterdam: Rodopi.

Holmes, J. S. (1988). Translated! Paper on Literary Translation and Translation Studies. Amsterdam: Rodopi.

Hunston, S. (1995). A corpus study of some English verbs of attribution. Functions of Language, 2, 133-158.

Hunston, S. (2002). Corpora in Applied Linguistics. Cambridge, London: Cambridge University Press.

Huston, S. (2010). How can a corpus be used to explore patterns? In A. O'Keeffe \& M. McCarthy (Eds.), The Routledge handbook of Corpus Linguistics (pp. 152-166). London/New York: Routledge.

Jakobson, R. (1959). On linguistic aspects of translation. On Translation, 3, 30-39.

Jiang, X., \& van Rij-Heyligers, J. (2008). Parallel corpus in Translation Studies: An intercultural approach. Paper presented at The International Symposium on Using Corpora in Contrastive and Translation Studies. Hangzhou, China, September.

Kenny, D. (2009). Corpora in translation studies. In M. Baker \& G. Saldanha (Eds.), Routledge encyclopaedia of Translation Studies ( $2^{\text {nd }}$ ed.) (pp. 50-53). New York: Routledge.

Kenny, D. (2014). Lexis and creativity in translation: A corpus based approach. London, England: Routledge.

Kersten, A.W., \& Earles, J. L. (2004). Semantic context influences memory for verbs more than memory for nouns. Memory \& Cognition, 32(2), 198-211.

Lakoff, G. (1993). The contemporary theory of metaphor". In A. Ortony, (Ed.), Metaphor and thought ( $2^{\text {nd }}$ ed.) (pp. 205-251). Cambridge, England: Cambridge University Press.

Lakoff, G. \& Johnson, M. (2003). Metaphors we live by. Chicago and London: The University of Chicago Press.

Langacker, R.W. (1987). Foundations of cognitive grammar: Theoretical prerequisites. Stanford, California: Stanford University Press.

Laviosa, S. (1998). The corpus-based approach: A new paradigm in translation studies. Meta: Translators' Journal, 43(4), 474-479.

Laviosa, S. (2002). Corpus-based Translation Studies: Theory, findings, applications (Vol. 17). Amsterdam: Rodopi.

Laviosa, S. (2011). Corpus Linguistics and Translation Studies. In V. Viana, S. Zyngier, \& G. Barnbrook (Eds.), Perspectives on Corpus Linguistics (pp. 131-153). Amsterdam/Philadelphia: John Benjamins.

Leech, G. (1997). Introducing corpus annotation. In R. Garside, G. Leech, \& A. McEnery (Eds.), Corpus annotation: Linguistic information from computer text corpora (pp. 1-18). London, England: Longman.

Linell, P. (1998). Approaching dialogue: Talk, interaction and context in dialogical perspectives. Amsterdam: John Benjamins.

Louw, B. (1993). Irony in the text or insincerity in the writer? The diagnostic potential of semantic prosodies. In M. Baker, G. Frances, \& T. Tognini-Bonelli (Eds.), Text and technology: In honour of John Sinclair (pp. 157-176). Amsterdam: John Benjamins.

McEnery, T., \& Wilson, A. (1993). Corpora and translation: Uses and future prospects. UCREL.

Mei-Hua, W. (2012). Frame semantics and the translation strategies of legal English. Journal of Yichun College, 5, 126-129.

Melamed, I. D. (1997). A word-to-word model of translational equivalence. Paper presented at Proceedings of the 35th Annual Meeting of the Association for Computational Linguistics and Eighth Conference of the European Chapter of the Association for Computational Linguistics, 490-497. Association for Computational Linguistics.

Minsky, M. (1974). A framework for representing knowledge. Artificial intelligence, 306, 1-82. 
Mosavi Miangah, T. (2006). Applications of corpora in translation. Translation Studies, 12, 43-56.

Object Management Group (OMG) (2015). Semantics of business vocabulary and business rules (SBVR) (version 1.3). Retrieved from http://www.omg.org/spec/ SBVR/1.3/.

Pan, Y. (2017). Framing university small group talk: Knowledge construction through lexical concepts. (Ph.D. Thesis). Newcastle University, UK.

Pan, Z., \& Kosicki, G. M. (1993). Framing analysis: An approach to news discourse. Political Communication, 10, 55-75.

Partington,A. (1998). Patterns and meaning. Using corpora for English language research and teaching. Amsterdam: John Benjamins.

Partington, A. (2004). Utterly content in each other's company: Semantic prosody and semantic preference. International Journal of Corpus Linguistics, 9, 131-156.

Petruck, M.R. (1996). Frame semantics and the lexicon: Nouns and verbs in the body frame. In M. Shibatani \& S. Thompson (Eds.), Essays in semantics and pragmatics: In honor of Charles J. Fillmore (pp. 279-297). Amsterdam/Philadelphia: John Benjamins.

Pica, T. (1994). Research on negotiation: what does it reveal about second language learning conditions, processes and outcomes? Language Learning, 44(3), 493-527.

Pym, A. (2007). Natural and directional equivalence in theories of translation. Target 19(2), 271-294.

Rayson, P. (2002). Matrix: A statistical method and software tool for linguistic analysis through corpus comparison. (Ph.D. Thesis). Lancaster University, UK.

Rayson, P. (2008). From key words to key semantic domains. International Journal of Corpus Linguistics, 13(4), 519-549.

Rayson, P., Archer, D., Piao, S., \& McEnery, T. (2004). The UCREL Semantic Analysis System, in Proceedings of the Workshop on Beyond Named Entity Recognition Semantic Labelling for NLP Tasks in Association with the 4th International Conference on Language Resources and Evaluation (LREC), 7-12. Retrieved from: http://eprints.lancs.ac.uk/12453/1/usas_lrec04ws.pdf

Rhoads, K. (1997). What's in a frame? Retrieved from: http://www.workingpsychology. $\mathrm{com} /$ whatfram.html

Rojo López, A. M. (2002). Applying frame semantics to translation: A practical example. Meta: Translators'Journal, 47(3), 312-350.

Rojo López, A. M., \& Valenzuela, J. (1998). Frame semantics and lexical translation the risk frame and its translation. Babel: Revue Internationale de la Traduction, 44(2), 128-138.

Rommetveit, R. (1992). Outlines of a dialogically based social-cognitive approach to human cognition and communication. In A.H. Wold (Ed.), The dialogical alternative: Towards a theory of language and mind (pp. 19-44). Oslo: Scandinavian University Press.

Schudson, M. (2003). The sociology of news. New York: W.W. Norton and Company.

Scott, M. (2010). What can corpus software do? In A. O'Keeffe \& M. McCarthy (Eds.), The Routledge handbook of Corpus Linguistics (pp. 136-151). Oxfordshire: Routledge.

Semetko, H. A., \& Valkenburg, P. M. (2000). Framing European politics: A content analysis of press and television news. Journal of Communication, 50, 93-109.

Semino, E. (2016). A Corpus-Based Study of "Mixed Metaphor" as a Metalinguistic Comment. In R. W. Gibbs Jr(Ed), Mixing Metaphor, （pp. 204-22). Amsterdam and Philadelphia, PA: John Benjamins.

Shi, D. (2008). Communication verbs in Chinese and English: A contrastive analysis. Languages in Contrast, 8(8), 181-207.

Sinclair, J. (1987). Collocation: A progress report. In R. Steele \& T. Threadgold (Eds.), Language topics: Essays in honour of Michael Halliday (Vol. 2, pp. 319-331). Amsterdam: John Benjamins.

Sinclair, J. (1996). The search for units of meaning. Textus, 9(1), 25-49.

Sinclair, J. M. (1991). Corpus, Concordance, Collocation. Oxford, England: Oxford University Press.

Snow, D., \& Benford, R. (1988). Ideology, frame resonance, and participant mobilization. International Social Movement Research, 1, 197-217.

Tankard, J. W. (2001). The empirical approach to the study of media framing. In S. D. Reese, O. H. Gandy, \& A. E. Grant (Eds.), Framing Public Life (pp. 95-106). Mahwah, NJ: Lawrence Erlbaum Associates. 
Stahl, G. (2006). Group cognition: Computer support for building collaborative knowledge. Cambridge, MA: MIT Press.

Stubbs, M. (1995). Collocations and semantic profiles. Functions of Language, 2(1), 23-55.

Sullivan, K. (2018). Mixed metaphors: Their use and abuse. London: Bloomsbury Academic.

Tannen, D. (1993). What's in a frame? Surface evidence for underlying expectations. In D. Tannen (Ed.), Framing in discourse (pp. 14-56). New York: Oxford University Press.

Telles-Ribeiro, B., \& Hoyle, S. M. (2009). Frame analysis. In F. Brisard, J.-O. Ostman, \& J. Verschueren (Eds.), Grammar, meaning and pragmatics (pp. 74-90). Amsterdam: John Benjamins.

Touri, M., \& Koteyko, N. (2014). Using corpus linguistic software in the extraction of news frames: Towards a dynamic process of frame analysis in journalistic texts. International Journal of Social Research Methodology, 18(6), 601-616.

Toury, G. (1978). The nature and role of norms in literary translation. In J. S. Holmes, J. Lambert, \& R. van den Broeck (Eds.), Literature and translation (pp. 83-100). Leuven: ACCO.

Toury, G. (2012). Descriptive Translation Studies - and beyond (Revised ed.). Amsterdam/Philadelphia: John Benjamins.

Toury, G. (1980). In search of a theory of translation. Tel Aviv: The Porter Institute for Poetics and Semiotics.

Trenz, H. (2004). 'Quo vadis Europe?' Quality newspapers struggling for European unity. Paper presented at the meeting of ARENA Centre for European Studies, Stirling.

Tuchman, G. (1978). Making news - A study in the construction of reality. London, England: The Free Press.

Tymoczko, M., \& Gentzler, E. (2002). Translation and power. Amherst: University of Massachusetts Press.

van de Steeg, M., Rauer, V., Rivet, S., \& Risse, T. (2003). The EU as a political community: A media analysis of the 'Haider Debate' in the European Union. Paper presented at the Annual Meeting of the European Union, Nashville.

Xiao, R., \& McEnery, T. (2006). Collocation, semantic prosody, and near synonymy: A cross-linguistic perspective. Applied Linguistics, 27(1), 103-129.

Yule, G. (1996). Pragmatics. Oxford, England: Oxford University Press.

\section{Appendix A. Source text}

The Guardian [editorial], Sunday 18 November 2012. Retrieved from: https://www.theguardian.com/commentisfree/2012/nov/18/editorial-britain-leavingeuropean-union 
If Britain leaves Europe, we will become a renegade without economic power.

An Observer poll shows majority in favour of EU exit - but the consequences of such a withdrawal would be dire..

Britain appears to be almost inexorably set on a course that will see it cease to be a full member of the European Union. Today's Observer opinion poll, suggesting that, offered a choice in a straight in/out referendum, a twoto-one majority of Britons would be inclined to leave is but another indicator of the strength of anti-European feeling. It is now almost certain that both of Britain's principal political parties will feel obliged to offer such a referendum in their manifestos for the next parliament, triggered by the Tories' anxiety to defend their flank against Ukip and Labour's need to match them to appease the wave of Euroscepticism. Unless Europe suddenly becomes more attractive or pro-Europeans can make a stronger argument, the result of any referendum could look inevitable.

The only qualification to that assumption might come from either party in government being able to offer the referendum on a renegotiated relationship with more powers ceded to Britain. On that thin reed, dependent on the goodwill of European states who no longer trust Britain's interest in building Europe, hangs our European future. We will either be a semi-detached member - or not a member at all.

The likelihood of a complete exit will be brought one step nearer by this week's European summit, where 27 states are trying to agree the EU's budget for the next seven years. Agricultural spending used to account for the lion's share of European spending; now, the bulk of expenditure goes towards the infrastructure of poorer members, on research and development, and on the implementation of pan-European initiatives such as the proposed banking union. A freeze in spending, given the acute needs of southem and eastern Europe, is unlikely; probably the other 26 will settle on a small, real-terms increase...

Britain will not concur. David Cameron, locked between his own increasingly confident Tory backbench Eurosceptics and an opportunistic Labour party that has put tactical advantage before principle, knows that he cannot get such a deal through Parliament, nor can it survive the hysterical scrutiny of the overwhelmingly centre-right Eurosceptic media. He will be compelled to veto the deal, entrenching the distrust between Britain and its European neighbours, and making any concessions even to win a referendum on a semi-detached relationship much less likely.

Tax avoidance and evasion will reach crippling levels as our economy becomes increasingly wholly owned by foreign multinationals that make tax avoidance in Britain central to their business strategy. No Eurosceptic ever complains about the selling of Britain to foreigners, a much greater constraint on our sovereignty than Brussels. Our fiscal and monetary policy will shadow that of the European authorities for fear of an attack on sterling if we do not..:

The best in Britain know this - most in the leadership teams of our main political parties including the Tory party, directors in our top companies, our cultural leaders, our trade union leaders, our universities and some of our public intellectuals. Yet collectively they are silent, bullied and cowed by the overwhelming media might of the Eurosceptics and losing heart because of the single currency crisis. Yet the EU is putting in place mechanisms for the euro's survival and even its prospering - a rescue and bail-out mechanism, a banking union, closer fiscal co-ordination and more political collaboration. The EU, the euro and the single currency will be here in a decade's time - our continent's instruments for managing globalisation/ and the challenges of the 21st century. We can be the renegade at the margins or playing our part in one of the great projects of our time. Those who believe in Europe need to start speaking out - and urgently. 
USAS Semantic Tagset

See http://ucrel.lancs.ac.uk/usas/ for more details.

\begin{tabular}{|c|c|c|c|c|}
\hline & IMONEY \& COMMERCE & S1.1.1. & General \\
\hline \multicolumn{2}{|c|}{$\begin{array}{l}\text { A GENERAL \& ABSTRACT TERMS } \\
\text { A1 General }\end{array}$} & I1 Money generally & S1.1.2 & Reciprocity \\
\hline A1.1.1. & General actions, making etc. & Money: Aflluence & S1.1.3 & Participation \\
\hline A1.1.2 & Damaging and destroying & Money: Debts & $\$ 1.1 .4$ & Deserve etc. \\
\hline A1.2 & Sutability & Money: Price & $\$ 1.2$ & Personality traits \\
\hline A1.3 & Caution & Business & S1.2.1 & Approachabability and Friendliness \\
\hline A1.4 & Chance, luck & Business: Generally & $\$ 1.2 .2$ & Avarice \\
\hline A1.5 & & Business: Selling & $\$ 1.23$ & Egoism \\
\hline A1.5.1 & Using & Work and employment & \$1.2.4 & Poilteness \\
\hline A1.5.2 & $\begin{array}{l}\text { Usefuluness } \\
\text { Phusialmential }\end{array}$ & $\begin{array}{l}\text { Work and employment: Generally } \\
\text { Wrk }\end{array}$ & $\begin{array}{l}S 1.2 .5 \\
\text { S1.26 }\end{array}$ & $\begin{array}{l}\text { Toughness; strongiweak } \\
\text { Sonsiblo }\end{array}$ \\
\hline $\begin{array}{l}A 1.6 \\
A 1.7\end{array}$ & $\begin{array}{l}\begin{array}{l}\text { Physical/mental } \\
\text { Constraint }\end{array} \\
\text { (a) }\end{array}$ & $\begin{array}{l}\text { Work and employment: Professionalism } \\
\text { Industry }\end{array}$ & $\begin{array}{l}\text { S1.2.6 } \\
\text { S2 }\end{array}$ & $\begin{array}{l}\text { Sensible } \\
\text { People }\end{array}$ \\
\hline & Inclusion:Exclusion & KENTERTAINMENT, SPORTS \& GAMES & s2.1 & People: Female \\
\hline A1.9 & Avoiding & $\mathrm{K} 1 \quad$ Entertainment generally & S2.2 & People: Male \\
\hline A2 & Affect & Music and related activities & s3 & Relationship \\
\hline A2.1 & Affect: Modify, change & Recorded sound etc. & S3.1 & Relationship: General \\
\hline A2.2 & Affect: Cause'Connected & Drama, the theatre $\&$ show business & $\mathrm{S} 3.2$ & Relationship: Intimatel sexual \\
\hline A4 & $\begin{array}{l}\text { Being } \\
\text { Classfication }\end{array}$ & $\begin{array}{l}\text { Sports and games generally } \\
\text { Sports }\end{array}$ & $\begin{array}{l}\$ 4 \\
\$ 5\end{array}$ & $\begin{array}{l}\text { Kin } \\
\text { Grouss and affiliation }\end{array}$ \\
\hline A4.1 & $\begin{array}{l}\text { Generally kinds, groups, examples } \\
\text { Genssing }\end{array}$ & $\begin{array}{l}\text { Sporis } \\
\text { Games }\end{array}$ & s6 & $\begin{array}{l}\text { Grioups and artuation } \\
\text { Obligation and necessity }\end{array}$ \\
\hline & Particular/general; detail & K6 Children's games and toys & s7 & $\begin{array}{l}\text { Power relationship } \\
\text { Powor }\end{array}$ \\
\hline A5 & Evaluation & L LIFE \& LVVING THINGS & $\$ 87.1$ & Power, organizing \\
\hline A5.1 & $\begin{array}{l}\text { Evaluation: Good/bad } \\
\text { Evaluation Truefalse }\end{array}$ & $\begin{array}{l}\text { Life and living things } \\
\text { Living creatures senerally }\end{array}$ & $\begin{array}{l}57.2 \\
\$ 73\end{array}$ & $\begin{array}{l}\text { Respect } \\
\text { Competition }\end{array}$ \\
\hline & $\begin{array}{l}\text { Evaluation: True/false } \\
\text { Evaluation: Accuracy }\end{array}$ & $\begin{array}{l}\text { Living creatures generally } \\
\text { Plants }\end{array}$ & $\begin{array}{l}\mathrm{S7.3} \\
\mathrm{S} 7.4\end{array}$ & $\begin{array}{l}\text { Competition } \\
\text { Permission }\end{array}$ \\
\hline & Evaluation: Authenticity & MMOVEMENT, LOCATION, TRAVEL \& TRANSPORT & $\begin{array}{l}58.4 \\
\mathrm{~S} 8\end{array}$ & Helpinghing hering \\
\hline$A 6$ & Comparing & M1 Moving, coming and going & S9 & Religion and the supernatural \\
\hline $\begin{array}{l}A 6.1 \\
A 6.2\end{array}$ & $\begin{array}{l}\text { Comparing: Similaldififerent } \\
\text { Comparing: Usual/unusual }\end{array}$ & $\begin{array}{l}\text { Putting, taking, pulling, pushing, transporting \&. } \\
\text { Movement transportation: land }\end{array}$ & TIME & Time \\
\hline & Comparing: Variety & Movementurtransportation: water & $\mathrm{T} 1.1$ & Time: General \\
\hline A7 & Definite (+ modals) & Movementtransportation: air & T1.1.1. & Time: General: Past \\
\hline A8 & Seem & Location and direction & T1.1.2 & Time: General: Present; simultaneous \\
\hline A9 & Getting and giving; possession & Places & $T 1.1 .3$ & Time: General: Future \\
\hline A10 & $\begin{array}{l}\text { Open/closed; Hiding/Hidden; } \\
\text { Findipe Shawing }\end{array}$ & M8 Remaining/stationary & $\mathrm{T} 1.2$ & $\begin{array}{l}\text { Time: Momentary } \\
\text { Time: Period }\end{array}$ \\
\hline A11 & $\begin{array}{l}\text { Finding, Showing } \\
\text { Importance }\end{array}$ & $\begin{array}{l}\text { N NUMBERS \& MEASUREMENT } \\
\text { N1 Numbers }\end{array}$ & 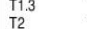 & \\
\hline A11.1 & Importance: Important & Mathematics & $T_{3}$ & $\begin{array}{l}\text { Ilimel: Beginining and ending } \\
\text { Time: Old, new and young; age }\end{array}$ \\
\hline A11.2 & Importance: Noticeabilty & Measurement & T4 & \\
\hline & Easydifficult & Measurement: General & W THE WOR & RLD \& OUR ENVIRONMENT \\
\hline A13 & Degree & Measurement: Size & $\mathrm{w}_{1}$ & $\begin{array}{l}\text { The universe } \\
\text { The }\end{array}$ \\
\hline A13.1 & Degree: Non-specific & Measurement: Distance & W2 & Light \\
\hline A13.2 & Degree: Maximizers & Measurement: Volume & W3 & Geographical terms \\
\hline A13.3 & $\begin{array}{l}\text { Degree: Boosters } \\
\text { Dons }\end{array}$ & Measurement: Weight & W4 & Weather \\
\hline A 13.4 & Degree: Approximators & Measurement: Area & W5 & Green issues \\
\hline A 13.5 & Degree: Compromisers & Measurement: Length \& height & X PSYCHOL & LOGICAL ACTIONS, STATES \& PROCESSES \\
\hline A13.6 & Degree: Diminishers & Measurement: Speed & $\mathrm{x} 1$ & General \\
\hline A13.7 & Degree: Minimizers & Linear order & $x_{2}$ & Mental actions and processes \\
\hline & Exclusivizers/particularizers & Quantities & $\mathrm{X} 2.1$ & Thought, belief \\
\hline A15 & Safety/Danger & Entirety; maximum & X2.2 & Knowledge \\
\hline B THE BOD & DY \& THE INDIVIDUAL & N5.2 Exceeding; waste & $x 2.3$ & Learn \\
\hline & $\begin{array}{l}\text { Anatomy and physiology } \\
\text { Health and disease }\end{array}$ & $\begin{array}{l}\text { Fro } \\
\text { Orequency elc. }\end{array}$ & $\begin{array}{l}\times 2.4 \\
\times 2.5\end{array}$ & $\begin{array}{l}\text { Investigatee, examine, test, search } \\
\text { Understand }\end{array}$ \\
\hline & Medicines and medical treatment & O1 Substances and materials generally & $\begin{array}{r}1.52 \\
\times 2.6\end{array}$ & $\begin{array}{l}\text { Expect } \\
\text { Exic }\end{array}$ \\
\hline & $\begin{array}{l}\text { Cleaning and personal care } \\
\text { Conth }\end{array}$ & Substances and materials generally: Sold & $x_{3}^{2.0}$ & Sensory \\
\hline & Clothes and personal belongings & Substances and materials generally: Liquid & $\mathrm{x} 3.1$ & Sensory: Taste \\
\hline CARTS \& & CRAFTS & Substances and materials generally: Gas & $\times 3.2$ & Sensory: Sound \\
\hline $\mathrm{C} 1 \mathrm{I}$ & Arts and crafts & Objects generally & $\hat{x} .3$ & Sensory: Touch \\
\hline E EMOTIOI & NAL ACTIONS, STATES \& PROCESSES & Electricity and electrical equipment & $\times 3.4$ & Sensory: Sight \\
\hline & General & Physical attributes & $\times 3.5$ & Sensory: Smell \\
\hline & Liking & General appearance and physical properties & $x_{4}$ & Mental object \\
\hline & Calm/Violent/Angry & Judgement of appearance (pretty etc.) & $\mathrm{X} 4.1$ & Mental object: Conceptual object \\
\hline & Happy/sad & Colour and colour patterns & $\mathrm{x} 4.2$ & Mental object: Means, method \\
\hline & Happyisad: Happy & Shape & $\times 5$ & Attention \\
\hline & $\begin{array}{l}\text { Happyssad: Contentment } \\
\text { Feprbcovenisholk }\end{array}$ & O4.5 Texture & $\begin{array}{c}x 5.1 \\
x_{5} .2\end{array}$ & Attention \\
\hline $\begin{array}{l}\text { E5 } \\
\text { E6 }\end{array}$ & $\begin{array}{l}\text { Fearbraverylyhock } \\
\text { Worry, concern, confident }\end{array}$ & $\begin{array}{l}\text { 04.6 Temperature } \\
\text { PEDUCATION }\end{array}$ & $\begin{array}{l}x_{5.2} \\
\times 6\end{array}$ & $\begin{array}{l}\text { Interestboredom/excitedienergetic } \\
\text { Deciding }\end{array}$ \\
\hline FFOOD \& 1 & FARMING & $\mathrm{P} 11$ Education in general & $\begin{array}{l}10 \\
\times 7\end{array}$ & $\begin{array}{l}\text { Deciding } \\
\text { Wanting; planning; choosing }\end{array}$ \\
\hline & Food & Q LINGUISTIC ACTIONS, STATES \& PROCESSES & $\mathrm{x}_{8}$ & Trying \\
\hline & Drinks & Communication & $\times 9$ & Ablity \\
\hline & Cigarettes and drugs & Communication in general & & Ablitity: Ability, intelligence \\
\hline & Farming \& Horticulture & Paper documents and writing & & Ability: Success and fallure \\
\hline GGOVT. \& & THE PUBLIC DOMAIN & Telecommunications & Y SCIENCE & \& TECHNOLOGY \\
\hline & Government, Politics \& elections & Speech acts & $\mathrm{Y}_{1}$ & Science and technology in general \\
\hline & $\begin{array}{l}\text { Government etc. } \\
\text { Politce }\end{array}$ & Speech etc: Communicative & $\mathrm{Y}_{2}$ & Intormation technology and computing \\
\hline & Politics & Speech acts & Z NAMES \& & GRAMMATICAL WORDS \\
\hline & Crime, law and order & Language, speech and grammar & zo & Unmatched proper nour \\
\hline & $\begin{array}{l}\text { Crime, law and order: Law \& order } \\
\text { General ethics }\end{array}$ & $\begin{array}{l}\text { The Media } \\
\text { The Media Books }\end{array}$ & $\begin{array}{l}\mathrm{Z1} \\
\mathrm{Z2}\end{array}$ & $\begin{array}{l}\text { Personal Inames } \\
\text { Geographical names }\end{array}$ \\
\hline & $\begin{array}{l}\text { Generale litics } \\
\text { Warfare, defence and the army: Weapons }\end{array}$ & $\begin{array}{l}\text { The Media Books } \\
\text { The Media Newspapers etc. }\end{array}$ & 22 & $\begin{array}{l}\text { Geographical names } \\
\text { Other proper names }\end{array}$ \\
\hline H ARCHITE & ECTURE, BUILDINGS, HOUSES \& THE HOME & The Media: TV, Radio \& Cinema & 24 & Discourse Bin \\
\hline H1 & $\begin{array}{l}\text { Architecture, kinds of houses \& buildings } \\
\text { a t }\end{array}$ & S SOCIAL ACTIONS, STATES \& PROCESSES & 25 & Grammatical bin \\
\hline & Parts of buildings & Social actions, states \& processes & $\mathrm{z} 6$ & Negative \\
\hline & Areas around or near houses & Social actions, states \& processes & 27 & II \\
\hline & $\begin{array}{l}\text { Residence } \\
\text { Furniture and household fttings }\end{array}$ & & & $\begin{array}{l}\text { Pronouns etc. } \\
\text { Trash }\end{array}$ \\
\hline & Furnture and household fittings & & ${ }_{299}^{29}$ & $\begin{array}{l}\begin{array}{l}\text { riash can } \\
\text { Unmatched }\end{array} \\
\text { S }\end{array}$ \\
\hline
\end{tabular}

